\title{
Physicochemical Characterization and Pesticide Residue Analysis of Honey Produced in West Shewa Zone, Oromia Region, Ethiopia
}

\author{
Eyobel Mulugeta, Wodaje Addis*, Lemessa Benti, Miresa Tadese
}

Department of Chemistry, Ambo University, Ambo, Ethiopia

Email address:

wedajeaddis@yahoo.com (W. Addis)

${ }^{*}$ Corresponding author

\section{To cite this article:}

Eyobel Mulugeta, Wodaje Addis, Lemessa Benti, Miresa Tadese. Physicochemical Characterization and Pesticide Residue Analysis of Honey Produced in West Shewa Zone, Oromia Region, Ethiopia. American Journal of Applied Chemistry. Vol. 5, No. 6, 2017, pp. $101-109$. doi: 10.11648/j.ajac.20170506.13

Received: October 9, 2017; Accepted: October 30, 2017; Published: December 8, 2017

\begin{abstract}
This study investigated physicochemical properties and pesticide residue levels of honey from West Shewa Zone, Ethiopia. The results of moisture, electrical conductivity, $\mathrm{pH}$, free acidity, reducing sugar, sucrose, ash, and total solids were found to be $16.61-18.64 \%, 0.384-0.646 \mathrm{mS} / \mathrm{cm}, 3.77-4.22,7.42-13.87 \mathrm{meq} / \mathrm{kg}, 61.38-72.87 \%, 6.84-15.94 \%, 0.030-0.095 \%$, and $81.36-83.28 \%$, respectively. Correlation analysis has shown moderate positive correlation at $\mathrm{P}<0.01$ between sucrose and ash $(r=0.555)$, and a strong negative correlation between moisture and total solids $(r=-0.9171)$. Residues of 4,4-DDD, 4,4DDT, Dieldrin, $\alpha$-Endosulfan, and $\beta$-Endosulfan were detected, among 20 organochlorine pesticides analyzed. Most physicochemical parameters have been found within the acceptable range set by national and international standards except sucrose content from Ejere and Toke Kutaye. The estimated daily intakes (EDIs) of pesticides identified in samples were below acceptable daily intakes (ADIs), that indicate honey ingesting has a negligible influence to toxicological risk.
\end{abstract}

Keywords: Honey, Physicochemical Properties, Honey Quality, Pesticide Residues, Estimated Daily Intakes

\section{Introduction}

Honey is a sweet and viscous substance produced by bees (Apis mellifera L.) and other related insects. Honeybees produce honey from the nectar of flowers or from the secretion of living parts of plants, in which honeybees transform through enzymatic activity and store it in wax structures called honeycombs until maturation [1-3]. Honey has been used by humans since ancient times in various foodstuffs and drinks as a sweetener and flavoring [4, 5].

Besides its nutritional benefits, honey has medicinal and therapeutic effects [6]. The properties of honey can be interpreted by its physicochemical composition [7]. It is estimated that fructose and glucose account for nearly 85 $95 \%$ in a complex mixture of carbohydrates, as well as other minor constituents, such as organic acids, amino acids, proteins, minerals, vitamins, and lipids are found in honey. Honey quality is usually determined by its sensorial, physicochemical and microbiological properties [8, 9].
The quality and physicochemical properties of honey depend on many factors such as, the type or types of plant that provided the nectar source of the honey, climatic conditions during productions, production methods, honey maturity, beekeeping practices in removing and extracting honey, processing and storage conditions [7, 10, 11]. Moreover, properties and compositions of honey depend on its geographical floral origin, kinds of bee species, season, environmental factors and treatment of beekeepers [12]. Therefore, determination of physicochemical parameters of honey is very significant to the honey industry, as these factors are intimately related to storage quality, granulation, texture, flavor, and the nutritional and medicinal values of honey $[7,10]$. Physicochemical parameters such as moisture, reducing sugar, sucrose, water insoluble, ash, free acid, $\mathrm{pH}$, electrical conductivity and specific rotation were used to determine the quality of honey, together with sensorial and microbiological characteristics [13]. Having the information about honey quality characteristics would allow the 
stakeholder's to pack and store the honey in proper conditions to preserve its quality and taste. In addition, it provides information regarding the energetic and nutritional quality, as well as the possibility of falsifying honey [10].

On the other hand, pesticide contaminations of food of animal origin have also been attracting attentions of many researches as major food quality parameter along with physicochemical parameters. As it is known, pesticides have played a very important role in the development of human agriculture since their invention, and they are still irreplaceable at present. However, the agricultural modernizing and the intensive agricultural production system were not beneficial for beekeepers. As the result, the population of honey bee colonies was declining in many parts of the world and even lead to extinction of some of the honeybee species. In addition, the pesticide residues becomes a potential risk to human health and have created trade disputes that have enhanced negative economic impacts in the food industry. Therefore, pesticide determination in bee products is also necessary to monitor contamination and guarantee consumer health [14, 15].

Physicochemical properties of honey have been investigated by many researchers around the globe. However, in Ethiopia, little work has been devoted to the study of properties of Ethiopian honeys [9, 13, 16-22]. To our knowledge, no body has studied the level of pesticide residues in Ethiopian honey.

West Shewa Zone which is located in Oromia Region in Western Ethiopia is identified as one of the potential areas for beekeeping in the country and honey is an important source of income for farmers in the area. However, reliable information on the bee plants, types of honey and nectar flow in this area is as yet highly limited and inadequate. To our knowledge, no research has been carried out to determine the physicochemical parameters and pesticide residue of honey from West Shewa Zone. Therefore, the present study was aimed to provide information on the physicochemical properties and pesticide residue of honey samples obtained from different Woredas of West Shewa Zone, Oromia Regional State, Ethiopia.

\section{Materials and Methods}

The honey samples were collected from six Woredas of West Shewa Zone of Oromia Regional State, Ethiopia. The samples were collected purposively from the most potential beekeeping Woredas namely Ambo, Dendi, Jeldu, Ejere, Adaberga and Toke Kutaye (Figure 1). A total of 90 honey samples of each weighing $0.5 \mathrm{~kg}$ (15 samples from each Woredas) were collected randomly from beekeepers during May-June 2016 and then samples were transferred to Ambo University Chemistry Laboratory under appropriate conditions for conducting physicochemical and pesticide residue analysis. Prior to analysis, unnecessary material such as wax sticks, dead bees and particles of combs were removed by draining the samples through cheesecloth and kept in a refrigerator at $4^{\circ} \mathrm{C}$ until analysis.

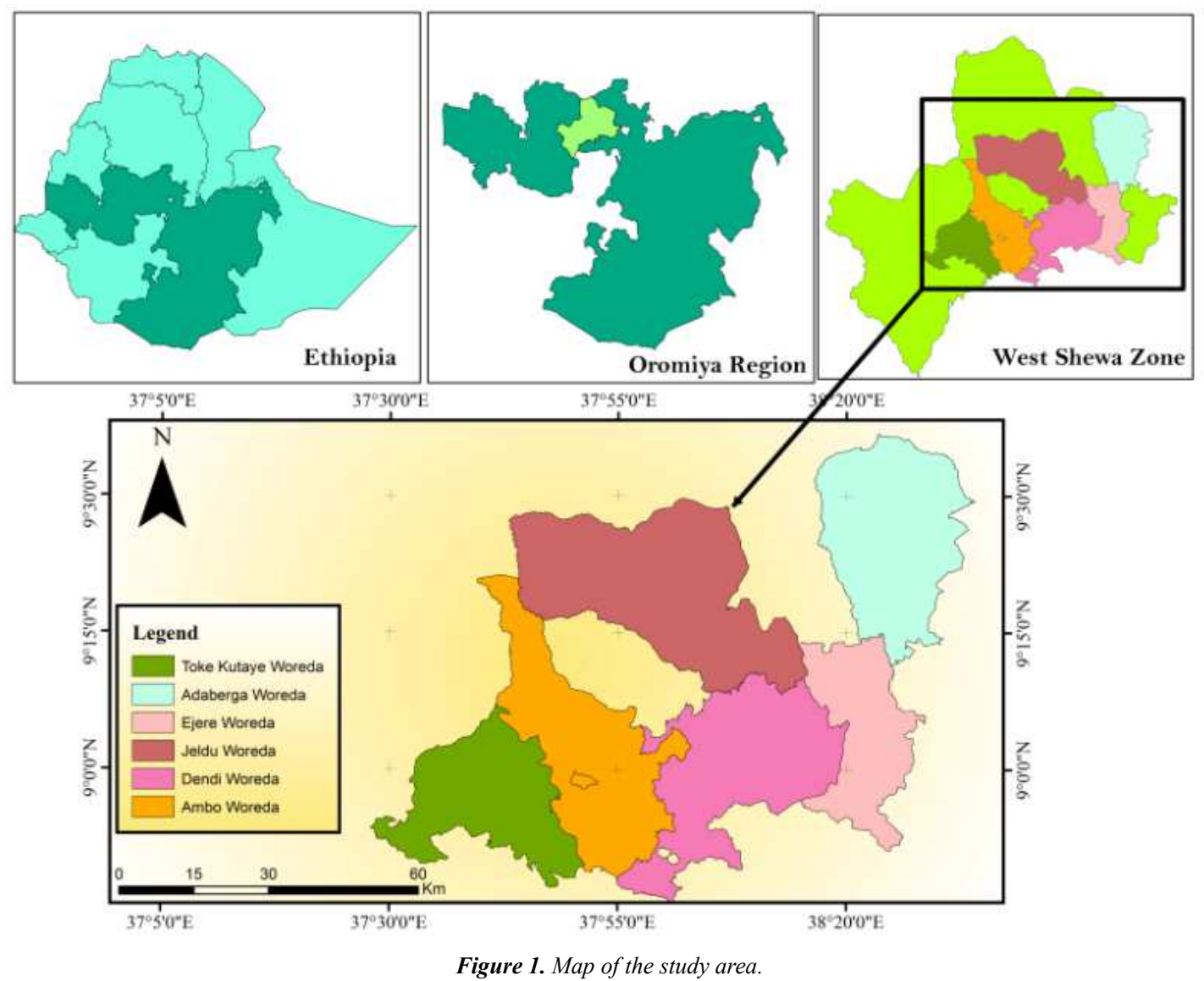




\subsection{Moisture}

The moisture content of each honey sample was determined according to Equation (1). About $5 \mathrm{~g}$ of the sample was placed in a pre-weighed aluminum dish. Then sample was dried to constant weight in an oven at $105^{\circ} \mathrm{C}$ for $4 \mathrm{~h}$ under vacuum [23].

$$
\text { Moisture content }=\frac{\mathrm{w}_{1}-\mathrm{w}_{2}}{W_{1}-W_{0}} \times 100
$$

where: $\mathrm{W}_{0}=$ Weight of aluminum dish $(\mathrm{g}), \mathrm{W}_{1}=$ Weight of the fresh sample + dish $(\mathrm{g})$ and $\mathrm{W}_{2}=$ Weight of the dried sample + dish $(\mathrm{g})$.

\subsection{Electrical Conductivity}

Conductivity meter (Model: SCHOTT handy lab LF11, Germany) was used to determine electrical conductivity of the sample. About $20 \mathrm{~g}$ of sample was mixed with $100 \mathrm{~mL}$ of distilled water in a $150 \mathrm{~mL}$ beaker and the mixture was stirred for about $1 \mathrm{~h}$ [1]. The instrument was calibrated using $0.01 \mathrm{M}$ potassium chloride $(\mathrm{KCl})$, which has an electrical conductivity of $1413 \mathrm{mS} / \mathrm{cm}$ at $25^{\circ} \mathrm{C}$.

\section{3. $\mathrm{pH}$}

The $\mathrm{pH}$ of the sample was measured by $\mathrm{pH}$ meter (Model: Elmetron CPI-501, Poland), which was calibrated with standard buffer solutions of $\mathrm{pH} 4.0$ and 7.0. Approximately $10 \mathrm{~g}$ of honey was mixed with $75 \mathrm{~mL}$ of distilled water in $150 \mathrm{~mL}$ beaker. The $\mathrm{pH}$ was recorded while stirring the solution [24].

\subsection{Free Acidity}

Free acidity was determined by mixing $10 \mathrm{~g}$ of honey with $75 \mathrm{~mL}$ of distilled water and then the mixture was titrated with $0.1 \mathrm{M} \mathrm{NaOH}$ solution until $\mathrm{pH}$ value became 8.3 [25, 26]. Free acidity in milliequivalens of acids $/ \mathrm{kg}$ of honey was calculated using AOAC 1990 official method 962.19 as follows [27, 28]:

Free acidity $(\mathrm{meq} / \mathrm{kg})=$ volume of $0.10 \mathrm{M} \mathrm{NaOH}(\mathrm{mL}) \times 10$

where, 10 indicates the dilution factor of honey sample during analysis.

\subsection{Reducing Sugar}

The percentage of total reducing sugar before and after inversion was calculated based on the relationship developed by Lane and Eynon in 1923 (Equation 3) and Codex Alimentarius Commission standards (Equation 4), respectively [22, 28, 29].

$$
\mathrm{C}=\frac{2}{\mathrm{~W}_{2}} \times \frac{1000}{\mathrm{Y}_{2}}
$$

where: $\mathrm{C}=\mathrm{g}$ total reduced sugar before inversion per $100 \mathrm{~g}$ honey, $\mathrm{W}_{2}=$ weight $(\mathrm{g})$ of honey sample and $\mathrm{Y}_{2}=$ volumes $(\mathrm{mL})$ of diluted honey solution consumed.

$$
C^{\prime}=\frac{2}{\mathrm{~W}_{2}} \times \frac{1000}{\mathrm{Y}_{2}}
$$

where: $\mathrm{C}^{\prime}=\mathrm{g}$ total reduced sugar after inversion per $100 \mathrm{~g}$ honey, $\mathrm{W}_{2}=$ weight $(\mathrm{g})$ of honey sample and $\mathrm{Y}_{2}=$ volumes $(\mathrm{mL})$ of diluted honey solution consumed.

\subsection{Sucrose}

The percentage of sucrose (non-reducing sugar) was estimated by subtracting reducing sugar content before inversion from reducing sugar content after inversion and then multiplying by a common factor:

$$
\text { Sucrose content }(\%)=\left(C^{\prime}-C\right) \times 0.95
$$

The result was presented as g apparent sucrose per $100 \mathrm{~g}$ honey, according to the procedure mentioned in Codex Alimentarius Commission standards [22, 28, 29].

\subsection{Ash}

About $5 \mathrm{~g}$ of each honey sample was weighed out into previously weighed porcelain crucible. Organic matter was charred by igniting the sample on a hot plate in the fume cupboard. The crucible was then placed in the muffle furnace and heated at $600^{\circ} \mathrm{C}$ for $6 \mathrm{~h}$. After complete ignition to constant weight, the sample was cooled in a desiccator and weighed immediately [23, 27]. The percent ash was calculated as:

$$
\operatorname{Ash}(\%)=\frac{\mathrm{w}_{1}-\mathrm{w}_{2}}{\mathrm{w}_{0}} \times 100
$$

Where: $\mathrm{W}_{0}=$ weight of honey sample taken $(\mathrm{g}), \mathrm{W}_{1}=$ weight of crucible + ash $(\mathrm{g})$ and $\mathrm{W}_{2}=$ weight of crucible $(\mathrm{g})$.

\subsection{Total Solids}

The percentage total solids was calculated using Equation (7) $[10,23]$.

$$
\text { Total solids }(\%)=100-\text { Moisture }
$$

\subsection{Statistical Analysis}

All the measurements were carried out in triplicates and the data were presented as means \pm standard deviations. Analysis of variance (ANOVA) was used to compare the quantified variables in the samples of honey. The significance was calculated for $\mathrm{P}<0.05$. Correlations among data obtained were calculated using Pearson's correlation coefficient (r). The statistical analyses were performed with the SPSS statistics version 16.0.

\subsection{Pesticide Residue Analysis}

The analyte of interest for pesticide residue analysis were 20 organochlorine pesticides commonly used in Ethiopia for controlling malaria and agricultural activities. These were Aldrin, $\alpha$-BHC, $\beta$-BHC, $\gamma$-BHC, Lindane, $\alpha$-chlorodan, $\gamma$ chlorodan, 4,4'DDD, 4,4'DDE, 4,4'DDT, Dieldrine, $\alpha-$ 
Endosulfan, $\beta$-Endosulfan, Endosulfan sulfate, Endrine, Endrine Aldehyde, Endrine Ketone, Heptachlor, Heptachlor Exo-epoxide, and Methoxychlor.

AOAC official method 2007.01 was used for analysis of pesticide in honey samples. In this particular method, the QuEChERS (quick, easy, cheap, effective, rugged, and safe) method has been used for extraction of pesticide from honey samples using a single-step buffered acetonitrile (MeCN) extraction and salting out liquid-liquid partitioning from the water in the sample with $\mathrm{MgSO}_{4}$ [30].

Pesticide standards were purchased from Dr. Eherst"orfer (Augsburg, Germany), with purity between 98.2 and $99.5 \%$. Acetonitrile (MeCN) high-performance liquid chromatography (HPLC) grade was obtained from J. T. Baker (USA) and the sorbent Bondesil primary secondary amine (PSA) from Agilent (USA). Anhydrous magnesium sulfate, acetic acid, and sodium acetate were obtained from Merck (China). Ultrapure water was prepared from a Milli-Q system (Millipore, Bedford, MA, USA).

An Agilent 7890B gas chromatograph connected to an Agilent 7000C GC-MS/MS triple Quadruple equipped with an autosampler (Agilent Technologies, USA) was used for detection of pesticide residues.

\section{Results and Discussion}

Table 1 shows the results obtained for the physicochemical analysis of the 90 honey samples collected from the study area.

Table 1. Physicochemical properties of honey samples (average \pm standard deviation).

\begin{tabular}{|c|c|c|c|c|c|c|}
\hline \multirow{2}{*}{ Parameters } & \multicolumn{6}{|c|}{ Location of Honey Sample } \\
\hline & Ambo & Dendi & Jeldu & Ejere & Adaberga & Toke Kutaye \\
\hline Moisture (\%) & $17.71 \pm 0.65$ & $17.33 \pm 1.12$ & $16.72 \pm 1.12$ & $18.05 \pm 1.48$ & $16.61 \pm 1.74$ & $18.64 \pm 1.25$ \\
\hline Conductivity (mS/cm) & $0.553 \pm 0.083$ & $0.545 \pm 0.063$ & $0.384 \pm 0.044$ & $0.646 \pm 0.09 z$ & $0.429 \pm 0.0436$ & $0.487 \pm 0.0989$ \\
\hline $\mathrm{pH}$ & $3.790 \pm 0.13$ & $3.820 \pm 0.36$ & $4.010 \pm 0.19$ & $4.22 z \pm 0.42$ & $4.091 \pm 0.21$ & $3.771 \pm 0.28$ \\
\hline Free Acidity (meq/kg) & $12.29 \pm 1.21$ & $7.420 \pm 0.084$ & $10.47 \pm 0.94$ & $11.07 \pm 1.13$ & $8.50 z \pm 1.47$ & $13.87 \pm 1.74$ \\
\hline Reducing Sugar (\%) & $61.38 \pm 1.12$ & $68.70 \pm 1.28$ & $72.87 \pm 1.20$ & $71.18 \pm 1.06$ & $66.61 \pm 1.36$ & $69.48 \pm 1.89$ \\
\hline Sucrose $(\%)$ & $2.280 \pm 0.39$ & $3.881 \pm 0.57$ & $4.842 \pm 0.55$ & $5.310 \pm 0.49$ & $2.601 \pm 0.51$ & $5.720 \pm 0.52$ \\
\hline Total Solid (\%) & $82.29 \pm 0.65$ & $82.68 \pm 1.12$ & $83.28 \pm 1.12$ & $81.95 \pm 1.48$ & $83.39 \pm 1.74$ & $81.36 \pm 1.25$ \\
\hline
\end{tabular}

\subsection{Moisture}

The moisture content in the investigated honey samples was found to be in the range of $16.61-18.64 \%$ (Table 1), which are within the limit $(\leq 20 \%)$ recommended by the international quality regulations [28, 31]. Generally, the moisture content of Adaberga honey recorded the lowest moisture content $(16.61 \pm 1.74 \%)$ among the analyzed samples, followed by Jeldu (16.72 \pm 1.12$)$, Dendi $(17.33 \pm$ 1.12), Ambo $(17.71 \pm 0.65)$ and Ejere $(18.05 \pm 1.48 \%)$, while Toke Kutaye honey showed the highest value of moisture content $(18.64 \pm 1.25 \%)$. There was no significant difference in the moisture content between the six types of honey samples $(\mathrm{P}>0.05)$. The results of this study on moisture content were also in agreement with the findings of Sisay et al. (2012) [18] who reported 15.01 to $18.16 \%$ and Gangwar et al. (2010) [16] who reported in the range of 15.2 to $18.2 \%$ in Ethiopian honey. El-Sohaimy et al. (2015) [12] also reported similar moisture content values (14.73-18.32\%) of honey samples from different origins. According to the Ethiopian Standard, ES (2005) [32], honey is grouped into three grades based on moisture content: Grade A: 17.519.0\%; Grade B: 19.1-20.0\%; and Grade C: 20.1-21.0\%. The West Shewa Zone honey could be grouped as 'Grade A' honey based on the Ethiopian standard.

Honey moisture is one of the quality criteria that determines the capability of honey to remain stable and to resist spoilage by yeast fermentation. The higher the moisture content is the higher probability of honey fermentation during storage [29]. Lower moisture content $(<20 \%)$, elongates honey shelf life during storage [12, 28]. However, the moisture content of honey depends on various factors, for example, the harvesting season, the degree of maturity reached in the hive and climatic factors $[33,34]$. Overall, the low moisture content in our honey samples indicates that all the samples have good storage ability and quality.

\subsection{Electrical Conductivity}

The electrical conductivity (EC) of the investigated honey samples ranged from 0.384 to $0.646 \mathrm{mS} / \mathrm{cm}$. The Ejere, Ambo and Dendi honey samples showed the highest EC $(0.642 \pm 0.092,0.553 \pm 0.083$ and $0.545 \pm 0.063 \mathrm{mS} / \mathrm{cm})$, respectively (Table 1). On the other hand, Toke Kutaye, Adaberga and Jeldu honey samples showed the lowest EC $(0.487 \pm 0.089,0.429 \pm 0.036$ and $0.384 \pm 0.041 \mathrm{mS} / \mathrm{cm})$, respectively. All the values were below the maximum limit of electrical conductivity $(\leq 0.800 \mathrm{mS} / \mathrm{cm})$ for honey recommended by the international quality regulations [28, 31]. There was no significant difference in the EC between examined samples $(\mathrm{P}>0.05)$. Our results indicated that the EC values of the honey samples were in agreement with those reported values of honey samples from Nigeria by Adenekan et al. (2010) [1] which ranges from 0.25-0.64 $\mathrm{mS} / \mathrm{cm}$, and honey samples from Malaysia by Moniruzzaman et al. (2013) [35] which ranges from $0.35-0.76 \mathrm{mS} / \mathrm{cm}$. The results of this study on EC were also in the range with the findings of Gangwar et al. (2010) [16] who reported 0.17 to $1.35 \mathrm{mS} / \mathrm{cm}$ in Ethiopian honey. However, the EC of this study were lower than the value reported by Belay et al. (2013) [13] in earlier studies of Ethiopian honey which was 
between 0.63 to $0.79 \mathrm{mS} / \mathrm{cm}$. Electrical conductivity varies with the botanical origin. Electrical conductivity is closely related to the concentration of minerals, acidity of honeys, organic acids and proteins, and it is a parameter that shows great variability depending on the floral source of honey [36].

\section{3. $\mathrm{pH}$}

The $\mathrm{pH}$ values of the honey samples ranged from $3.77-$ 4.22 (Table 1), which were in the standard range of 3.3-4.6 specified by the Codex Alimentarius Commission [28]. Therefore, it was found that all the studied honey samples were acidic in nature. Among all the honey samples, Toke Kutaye honey was the most acidic $(\mathrm{pH} 3.77 \pm 0.28)$ followed by Ambo honey $(3.79 \pm 0.13)$. The $\mathrm{pH}$ values of Dendi, Jeldu, and Adaberga honey were: $3.82 \pm 0.36,4.01 \pm 0.19$ and $4.09 \pm 0.21$, respectively. The lowest acidity was detected in Ejere honey $(4.22 \pm 0.42)$. There was no significant difference recorded between the six studied types of honey concerning $\mathrm{pH}$ values $(\mathrm{P}>0.05)$. Our results were in the range indicated by Kayode and Oyeyemi (2014) [10] who reported that the $\mathrm{pH}$ of honey was between 3.73 and 4.60 in Nigeria honey and Reshma et al. (2016) [34] who reported that the acidic $\mathrm{pH}$ of honey was between 3.40 and 4.60 in India honey. Similarly, the results of our findings agree with those previously reported studies in different locations of Ethiopia [16, 17, 21, 22].

The low $\mathrm{pH}$ of honey has an advantage to prevent the presence and growth of microorganisms. In addition, the $\mathrm{pH}$ of honey mainly indicates the buffering action of the inorganic cation constituents of the acids present. $\mathrm{pH}$ values have great importance during the extraction and storage of honey as it influences the texture, stability and shelf life of honey [34, 37].

\subsection{Free Acidity}

The free acidity values of the honey analyzed ranged from 6.58 to $15.61 \mathrm{meq} / \mathrm{kg}$ (Table 1). All the honey samples have shown a free acidity level less than $50 \mathrm{meq} / \mathrm{kg}$, which was the maximum limit allowed for good quality honey prescribed by Codex Alimentarius (2001) [28] and EU (2002) [31]. These values were within the prescribed limits of $40 \mathrm{meq} / \mathrm{kg}$ as proposed by the Ethiopian standard [32]. The Toke Kutaye honey sample has shown the highest values free acidity (13.87 $\mathrm{meq} / \mathrm{kg}$ ) while the Dendi honey sample has shown the lowest values of free acidity $(7.42 \mathrm{meq} / \mathrm{kg})$. In contrast to our results, Gangwar et al. (2010) [16] reported 18.9-32.3 meq $/ \mathrm{kg}$ free acidity of honey produced by different plant species in Ethiopia, and Kayode and Oyeyemi (2014) [10] reported free acidity of Nigerian honey that ranged from $21.5-33.6 \mathrm{meq} / \mathrm{kg}$. There was significant difference in the free acidity between the six types of honey samples $(\mathrm{P}<0.05)$. This result revealed that the freshness of honey samples and the absence of unwanted fermentation $[33,34]$. None of the samples exceeded the limit set, which may be taken as indicative of freshness of all the honey samples of the study area. Variation in free acidity among different honeys can be attributed to floral origin or to variation in the harvest season [34].

\subsection{Reducing Sugar}

The reducing sugars values of honey analyzed in the present study were ranged between $61.38-72.87 \%$. Jeldu honey showed the highest value of reducing sugars $(72.87 \pm$ $1.20 \%$ ), while Ambo honey showed the lowest value of reducing sugars $(61.38 \pm 1.12 \%)$. Ejere, Toke Kutaye, Dendi and Adaberga honey have showed $71.18 \pm 1.06,69.48 \pm$ $1.89,68.70 \pm 1.28$ and $66.61 \pm 1.36 \%$, respectively (Table 1 ) which fulfilled the requirements of Ethiopian standard (2005) [32] and Codex Alimentarius Commission (2001) [28]. Therefore, all honey samples were qualified an international standard for content of reducing sugars in honey. There was no significant difference $(p>0.05)$ in the amount of reducing sugars among honey samples analyzed from all the six locations. The results of this study on reducing sugar were also in agreement with the findings of Sisay et al. (2012) [18] who reported 62.0 to $71.0 \%$ in honey samples analyzed from Homesha District of Western Ethiopia, Tewedros et al. (2013) [19] who reported 63.4 to $71.7 \%$ in honey samples analyzed from Sekota District, Northern Ethiopia and Awraris et al. (2014) [9] who reported 64.78 to $69.27 \%$ in Ethiopian honey analyzed from Southwestern Ethiopia. Similar results also reported by Kumar et al. (2013) [38] in Indian honey that ranged from $62.24-70.24 \%$. The high sugar content of the investigated honey samples could be attributed to its high acidity and low moisture content.

\subsection{Sucrose}

The sucrose content of the investigated honey samples ranged between 2.60 to $5.72 \%$ (Table 1). ANOVA test showed that there was a significant difference in the sucrose content between examined samples $(\mathrm{P}<0.05)$. Similar values were observed by Tewedros et al. (2013) [19] that ranged between 1.0 to $5.2 \%$ and Awraris et al. (2014) [9] that ranged between 1.68 to $6.37 \%$ in previous studies of Ethiopian honey. All the honey samples fulfilled the requirements of sucrose content set by Ethiopian standard (2005) [32] which is $<10 \%$ but the honey samples from Ambo, Dendi, Jeledu and Adaberga qualified for the requirements of international regulations, which should not contain more than 5\% Codex Alimentarius (2001) [28]; and European Union (2002) [31], while the Ejere and Toke Kutaye honey were having a slight excess value of sucrose than the international standard of Codex Alimentarius. The slight excess value of sucrose content of honey from Ejere and Toke Kutaye may be due to adulteration of the honey by addition of commercial sugar to honey.

\subsection{Ash}

Ash content was considered to be an indicator of the cleanliness of honey samples [39]. The ash content in honey is generally small and depends on nectar composition of predominant plants in their formation [7]. The ash content in the investigated honey samples were varied between 0.030 $0.095 \%$ (Table 1). The Ejere honey sample had higher ash 
content $(0.095 \%)$ where Adaberga honey sample had lower ash content $(0.030 \%)$. The ash content of all the analyzed honey samples lied within the acceptable range $0.01-1.2 \%$ set by the Ethiopian standard, Admasu and Nuru (2000) [40] and below $0.6 \%$ maximum limit set by the International Honey Commission, Bogdanov (1997) [29] for mineral content of honey. There was significant difference between samples in ash content $(\mathrm{P}<0.05)$. The results of our findings were in agreement with those found by Gangwar et al. (2010) [16] and Tewedros et al. (2013) [19]. They reported as 0.014 to $0.314 \%$ and 0.01 to $0.52 \%$, respectively for Ethiopian honey. Similar values were reported by Kayode and Oyeyemi (2014) [10] in Nigeria honey that ranged from 0.004 to $0.440 \%$. However, the values were very low compared to the previous works of Awraris et al. (2014) [9] who reported a range of $0.1-0.40 \%$ and Bekele et al. (2016) [22] who reported a range of $0.14-0.30 \%$ in Ethiopia honey. Variation in the ash content of the honey samples might be due to differences in the floral origin of the honeys. The ash content is a measure of mineral content of honey. Though the quantities of minerals are less, they play a vital role in determining the color and nutritional value of honey [41].

\subsection{Total Solid}

The total solids values in honeys from all studied areas were very high. They ranged between $81.36-83.39 \%$ (Table 1) indicating that they were within the acceptable total solids range. There was no significant difference $(p>0.05)$ in the amount of total solid among honey samples analyzed from all the six locations. The results of this study on total solid were also in agreement with the previous work of Lawal et al. (2009) [42] who reported 80.00 to $84.00 \%$ in Nigerian honey. Similarly, these results were in agreement with the findings of Kayode and Oyeyemi (2014) [10] who reported the values of free acidity from Nigeria honey that ranged between 76.6$90.73 \%$.

\subsection{Correlation Analysis}

The Pearson correlation coefficients (r) values between the analyzed physicochemical properties of the studied honey samples are presented in Table 2. There were moderate positive correlations (Pearson correlation coefficient significant at $\mathrm{P} \leq 0.01)$ between sucrose and ash content $(\mathrm{r}=$ $0.555)$, between ash and $\mathrm{pH}(\mathrm{r}=0.461$ at $\mathrm{P} \leq 0.05)$, and between sucrose and reducing sugar $(\mathrm{r}=0.461$ at $\mathrm{P} \leq 0.05)$. There was also a weak positive correlation between free acidity with moisture $(\mathrm{r}=0.363)$, conductivity with moisture $(\mathrm{r}=0.246)$, sucrose with moisture $(\mathrm{r}=0.322)$, ash with free acidity $(\mathrm{r}=0.262)$, ash with reducing sugar $(\mathrm{r}=0.366), \mathrm{pH}$ with conductivity $(\mathrm{r}=0.284)$, and free acidity with conductivity $(\mathrm{r}=0.249)$. However, there were strong negative correlations (Pearson correlation coefficient significant at $\mathrm{P} \leq 0.01)$ between moisture content and total solid $(\mathrm{r}=-0.917)$. There was a moderate negative correlation between free acidity and total solid $(\mathrm{r}=-0.413$ at $\mathrm{P} \leq 0.05)$. There was also a weak negative correlation between sucrose and total solid $(\mathrm{r}=-0.329)$, electrical conductivity and total solid $(\mathrm{r}=-0.250)$. The other correlations are very weak.

Table 2. Pearson correlation coefficients (r) between physicochemical properties of studied honey.

\begin{tabular}{|c|c|c|c|c|c|c|c|c|}
\hline & Moisture & Conductivity & pH & Free acidity & Reducing sugar & Sucrose & Ash & Total solid \\
\hline Moisture & 1 & & & & & & & \\
\hline Conductivity & 0.246 & 1 & & & & & & \\
\hline $\mathrm{pH}$ & 0.004 & 0.284 & 1 & & & & & \\
\hline Free acidity & 0.363 & 0.249 & -0.071 & 1 & & & & \\
\hline Reducing sugar & 0.080 & -0.074 & 0.131 & 0.118 & 1 & & & \\
\hline Sucrose & 0.322 & -0.006 & 0.094 & 0.179 & $0.461^{*}$ & 1 & & \\
\hline Ash & 0.116 & 0.169 & $0.461^{*}$ & 0.262 & 0.366 & $0.555 * *$ & 1 & \\
\hline
\end{tabular}

**. Correlation is significant at the 0.01 level (2-tailed).

*. Correlation is significant at the 0.05 level (2-tailed).

\subsection{Residual Pesticide Levels}

Of the 20 honey samples analyzed, there were only 5 pesticides were found higher than the detection limits (Table 3 ). Residues of 3 organochlorine pesticides such as 4,4-DDD, 4,4 -DDT and $\alpha$-Endosulfan, were found in most samples (Table 4). Also, residues of Dieldrin and $\beta$-Endosulfan were found in a few samples. The presence of low levels of residues has been attributed to the earlier applications of these pesticides in controlling Malaria by Ethiopian Ministry of Health and also by the Ministry of Agriculture to control pests. In some places where the beekeepers were still using old and traditional honey production systems, and thus the accumulation of residual pesticides through time might be associated with high levels of pesticides in honey samples analyzed.

Table 3. Limit of detection (LOD) and mean recovery (\%) of the analyzed samples.

\begin{tabular}{lll}
\hline Organochlorine pesticides & Limit of detection $\mathbf{( m g / K g})$ & \% Mean recovery after PSA clean-up \\
\hline Aldrin & 0.003 & 93.58 \\
$\alpha$-BHC & 0.001 & 97.68 \\
$\beta$-BHC & 0.005 & 103.1 \\
$\gamma$-BHC & 0.002 & 98.28 \\
Lindane & 0.001 & 99.35 \\
\hline
\end{tabular}




\begin{tabular}{lll}
\hline Organochlorine pesticides & Limit of detection $\mathbf{( m g / K g})$ & \% Mean recovery after PSA clean-up \\
\hline$\alpha$-chlorodan & 0.003 & 98.51 \\
$\gamma$-chlorodan & 0.001 & 100.9 \\
4,4'DDD & 0.005 & 118.1 \\
4,4'DDE & 0.002 & 104.3 \\
4,4'DDT & 0.004 & 109.5 \\
Dieldrine & 0.003 & 117.2 \\
$\alpha$-Endosulfan & 0.006 & 115.8 \\
$\beta$-Endosulfan & 0.005 & 106.3 \\
Endosulfan sulfate & 0.002 & 109.4 \\
Endrine & 0.007 & 129.4 \\
Endrine Aldehyde & 0.003 & 106.4 \\
Endrine Ketone & 0.003 & 101.5 \\
Heptachlor & 0.001 & 101.24 \\
Heptachlor Exo-epoxide & 0.001 & 108.50 \\
Methoxychlor & 0.001 & 106.7 \\
\hline
\end{tabular}

Table 4. Pesticide residues detected in honey samples. $<D L$ means below the detection limit.

\begin{tabular}{|c|c|c|c|c|c|c|}
\hline \multirow{3}{*}{ Name of Organochlorine pesticides } & \multicolumn{6}{|c|}{ Name of Woredas found in West Shewa Zone } \\
\hline & Ambo & Dendi & Jeldu & Ejere & Adaberga & Toke Kutaye \\
\hline & \multicolumn{6}{|c|}{ Levels of pesticide residues $(\mathrm{mg} / \mathrm{kg})$} \\
\hline Aldrin & $<\mathrm{DL}$ & $<\mathrm{DL}$ & $<\mathrm{DL}$ & $<\mathrm{DL}$ & $<\mathrm{DL}$ & $<\mathrm{DL}$ \\
\hline$\alpha$-BHC & $<\mathrm{DL}$ & $<\mathrm{DL}$ & $<\mathrm{DL}$ & $<\mathrm{DL}$ & $<\mathrm{DL}$ & $<\mathrm{DL}$ \\
\hline$\beta$-BHC & $<\mathrm{DL}$ & $<\mathrm{DL}$ & $<\mathrm{DL}$ & $<\mathrm{DL}$ & $<\mathrm{DL}$ & $<\mathrm{DL}$ \\
\hline$\gamma$-BHC & $<\mathrm{DL}$ & $<\mathrm{DL}$ & $<\mathrm{DL}$ & $<\mathrm{DL}$ & $<\mathrm{DL}$ & $<\mathrm{DL}$ \\
\hline Lindane & $<\mathrm{DL}$ & $<\mathrm{DL}$ & $<\mathrm{DL}$ & $<\mathrm{DL}$ & $<\mathrm{DL}$ & $<\mathrm{DL}$ \\
\hline$\alpha$-chlorodan & $<\mathrm{DL}$ & $<\mathrm{DL}$ & $<\mathrm{DL}$ & $<\mathrm{DL}$ & $<\mathrm{DL}$ & $<\mathrm{DL}$ \\
\hline$\gamma$-chlorodan & $<\mathrm{DL}$ & $<\mathrm{DL}$ & $<\mathrm{DL}$ & $<\mathrm{DL}$ & $<\mathrm{DL}$ & $<\mathrm{DL}$ \\
\hline 4,4'DDD & 0.021 & 0.023 & 0.035 & 0.031 & 0.028 & 0.008 \\
\hline 4,4'DDE & $<\mathrm{DL}$ & $<\mathrm{DL}$ & $<\mathrm{DL}$ & $<\mathrm{DL}$ & $<\mathrm{DL}$ & $<\mathrm{DL}$ \\
\hline 4,4'DDT & $<\mathrm{DL}$ & $<\mathrm{DL}$ & 0.0050 & 0.0048 & 0.0043 & 0.0050 \\
\hline Dieldrine & $<\mathrm{DL}$ & $<\mathrm{DL}$ & $<\mathrm{DL}$ & 0.009 & $<\mathrm{DL}$ & 0.011 \\
\hline$\alpha$-Endosulfan & 0.0117 & 0.0134 & 0.0220 & 0.0228 & 0.0122 & 0.0143 \\
\hline$\beta$-Endosulfan & 0.0060 & 0.0060 & $<\mathrm{DL}$ & $<\mathrm{DL}$ & $<\mathrm{DL}$ & 0.0070 \\
\hline Endosulfan sulfate & $<\mathrm{DL}$ & $<\mathrm{DL}$ & $<\mathrm{DL}$ & $<\mathrm{DL}$ & $<\mathrm{DL}$ & $<\mathrm{DL}$ \\
\hline Endrine & $<\mathrm{DL}$ & $<\mathrm{DL}$ & $<\mathrm{DL}$ & $<\mathrm{DL}$ & $<\mathrm{DL}$ & $<\mathrm{DL}$ \\
\hline Endrine Aldehyde & $<\mathrm{DL}$ & $<\mathrm{DL}$ & $<\mathrm{DL}$ & $<\mathrm{DL}$ & $<\mathrm{DL}$ & $<\mathrm{DL}$ \\
\hline Endrine Ketone & $<\mathrm{DL}$ & $<\mathrm{DL}$ & $<\mathrm{DL}$ & $<\mathrm{DL}$ & $<\mathrm{DL}$ & $<\mathrm{DL}$ \\
\hline Heptachlor & $<\mathrm{DL}$ & $<\mathrm{DL}$ & $<\mathrm{DL}$ & $<\mathrm{DL}$ & $<\mathrm{DL}$ & $<\mathrm{DL}$ \\
\hline Heptachlor Exo-epoxide & $<\mathrm{DL}$ & $<\mathrm{DL}$ & $<\mathrm{DL}$ & $<\mathrm{DL}$ & $<\mathrm{DL}$ & $<\mathrm{DL}$ \\
\hline Methoxychlor & $<\mathrm{DL}$ & $<\mathrm{DL}$ & $<\mathrm{DL}$ & $<\mathrm{DL}$ & $<\mathrm{DL}$ & $<\mathrm{DL}$ \\
\hline
\end{tabular}

The potential health risks were estimated based on EDIs, which is related with exposure to detected pesticides. Estimated daily intake (EDI) was determined for the detected pesticide residues in the honey sample following the international guidelines WHO (1997) [43] and FAO (2002), [44]:

$$
\mathrm{EDI}=\Sigma \mathrm{C} \times \mathrm{F} /(\mathrm{D} \times \mathrm{W})
$$

where, $\mathrm{C}$ is the mean of pesticide residues concentration in honey $(\mu \mathrm{g} / \mathrm{kg}), \mathrm{F}$ is mean annual intake of honey per person
(2 $\mathrm{kg}$ per person approximately), D is number of days in a year (365), and $\mathrm{W}$ is mean body weight $(60 \mathrm{~kg})$.

The estimated daily intakes of pesticides identified in the sample were below the ADIs, which indicated that honey consumption has a negligible influence to health risk (Table 5). If the hazard index of the pesticide residue is lower than unity, then the consumer is considered to be adequately safe. The hazard index values showed that all the intakes of pesticide residues remain clearly below the safe limit.

Table 5. Estimated daily intakes (EDIs) and acceptable daily intakes (ADIs) of detected pesticide residues.

\begin{tabular}{llll}
\hline Pesticide & ADI $(\boldsymbol{\mu g} / \mathbf{k g}$ body weight/day) & EDI $(\boldsymbol{\mu g} / \mathbf{k g}$ body weight/day) & Hazard index (EDI/ADI, \%) \\
\hline 4,4-DDD & 20 & 0.0022 & 0.0111 \\
4,4-DDT & 20 & 0.0004 & 0.0022 \\
$\alpha$-Endosulfan & 6 & 0.0009 & 0.9132 \\
$\beta$-Endosulfan & 6 & 0.0015 & 0.0245 \\
Dieldrin & 0.1 & 0.0006 & 0.0096 \\
\hline
\end{tabular}




\section{Conclusions}

The physicochemical properties and pesticide residue of honey samples collected from six Woredas of West Shewa Zone of Oromia Regional State Ethiopia were analyzed. The results of this study may serve as a base line data for researchers. Physicochemical properties data have shown that almost all the samples of honey analyzed were within the acceptable range of Ethiopian Standard, European Standard and Codex Alimentarius except sucrose content from Ejere and Toke Kutaye. From statistical analysis, there were significant differences $(p<0.05)$ in the quantity of free acidity, ash and sucrose content of the honey samples but there were no significance differences $(p>0.05)$ in the values of moisture, $\mathrm{pH}$, conductivity, reducing sugar and total solids analyzed from the different locations. Pearson correlation analysis showed moderate correlation coefficients between sucrose and ash, and strong negative correlation between moisture and total solid. The pesticide analysis results obtained from this study indicated that the accumulation of residual pesticides in honey due to earlier applications of these pesticides in controlling pests in particular malaria and also poor beekeeping practice were lad to lower level of pesticide residues in honey. However, the risk associated with exposure of pesticide through honey consumption was negligible. Continuous monitoring of quality of the honey and upgrading standards of production, processing, packaging and distribution conditions are necessary. In addition, beekeepers should be well trained in honey harvesting and storage for further improvement on the quality of honey. However, further studies are needed to evaluate the quality of the studied honeys based on nutritional, medicinal, and antioxidant properties.

\section{Acknowledgements}

This research was supported by grants from Ambo University (grant number: CNCS/CHEM/14/2).

\section{References}

[1] Adenekan, M. O.; Amusa, N. A.; Lawal, A. O.; Okpeze, V. E., Physico-chemical and Microbiological Properties of Honey Samples Obtained from Ibadan. Journal of Microbiology and Antimicrobials 2010, 2, 100-104.

[2] Kavapurayil, J. B.; Karalam, S.; Chandran, R. P., Analysis of Physicochemical, Biochemical, and Antibacterial Properties of Indian Honey Samples with Special Reference to their Nonconformity. Acta Alimentaria 2014, 43, 9-18.

[3] Awad, M. H.; Elgornazi, A. M., Physicochemical Characterization of Honey from Kasr Khiar and Garaboli Areas-Libya. Asian Journal of Plant Science and Research 2016, 6, 8-12.

[4] Kowsalya, V., Antibacterial Activity of Honey and Erytlaria Acualis against Bacteria Isolated from Burnt Wound Sepsis. IOSR Journal of Pharmacy and Biological Sciences 2012, 1, 1-2.
[5] Omoya, F. O.; Ijabadeniyi, O. A.; Ogonnoh, O. B., Physicochemical Properties of Honey Samples from Ondo State, Nigeria, and their Bioactivity against Spoilage and Pathogenic Organisms. Journal of Food, Agriculture and Environment 2014, 12, 104-107.

[6] Delphine, D. N.; Joseph, T., Palynological and Physicochemical Characterization of Honey in the SudanoGuinean Zone of Cameroon. Food and Nutrition Sciences 2015, 6, 1339-1350.

[7] Gairola, A.; Tiwari, P.; Tiwari, J. K., Physico-chemical Properties of Apis Cerana-indica F. Honey from Uttarkashi District of Uttarakhand, India. Journal of Global Biosciences 2013, 2, 20-25.

[8] Gomes, S.; Dias, L. G.; Moreira, L. L.; Rodrigues, P.; Estevinho, L., Physicochemical, Microbiological and Antimicrobial Properties of Commercial Honeys from Portugal. Food and Chemical Toxicology 2010, 48, 544-548.

[9] Awraris, G.; Hailemariam, G.; Dejen, A.; Zerihun, T., Physico-chemical Properties of Honey Produced in Masha, Gesha, and Sheko Districts in South-western Ethiopia. Current Research in Agricultural Sciences 2014, 1, 110-116.

[10] Kayode, J.; Oyeyemi, S. D., Physico-chemical Investigation of Honey Samples from Bee Farmers in Ekiti State, Southwest Nigeria. Journal of Plant Sciences 2014, 2, 246-249.

[11] Oyeyemi, S. D.; Kayode, J.; Owolabi, M. O., Comparative Nutritional Studies on Honey Samples in Ado Ekiti, Ekiti State, Nigeria. Donnish Journal of Medicinal Plant Research 2015, 2, 016-020.

[12] El-Sohaimy, S. A.; Masry, S. H. D.; Shehata, M. G., Physicochemical Characteristics of Honey from Different Origins. Annals of Agricultural Sciences 2015, 60, 279-287.

[13] Belay, A.; Solomon, W. K.; Bultossa, G.; Adgaba, N.; Melaku, S., Physicochemical Properties of the Harenna Forest Honey, Bale, Ethiopia. Food Chemistry 2013, 141, 3386-3392.

[14] Blasco, C.; Vazquez-Roig, P.; Onghena, M.; Masia, A.; Picó, Y., Analysis of Insecticides in Honey by Liquid Chromatography-ion Trap-mass Spectrometry: Comparison of Different Extraction Procedures. Journal of Chromatography A 2011, 1218, 4892-4901.

[15] European Union Reference Laboratory (EURL), Pesticides Residues in Food of Animal Origin and Commodities with High Fat Content, European Commission, Freiburg, Germany, 2012.

[16] Gangwar, S. K.; Gebremariam, H.; Ebrahim, A.; Tajebe, S., Characteristics of Honey Produced by Different Plant Species in Ethiopia. Advances in Bioresearch 2010, 1, 101-105.

[17] Kebede, N; Subramanian, P. A.; Gebrekidan, M., Physicochemical Analysis of Tigray Honey: An Attempt to Determine Major Quality Markets of Honey. Bulletin of the Chemical Society of Ethiopia 2012, 26, 127-133.

[18] Sisay, G.; Eyasu S.; Amsalu, B., Physicochemical Properties of Honey Produced in the Homesha District of Western Ethiopia. Journal of Apicultural Science 2012, 56, 33-40.

[19] Tewodros, A.; Eyassu, S.; Amsalu, B., Physicochemical Properties of Honey Produced in Sekota District, Northern Ethiopia. International Food Research Journal 2013, 20, 3061-3067. 
[20] Tadesse, G.; Gebregziabher, B., Determination of Quality and Adulteration Effects of Honey from Adigrat and its Surrounding Areas. International Journal of Technology Enhancements and Emerging Engineering Research 2014, 2, $71-76$.

[21] Gebru, E.; Berhanu, A.; Hayal, L.; Solomon, A., Physicochemical Characterization of Honey from DebreNazret Kebele of Tigray Region, Ethiopia. World Applied Sciences Journal 2015, 33, 1806-1814.

[22] Bekele, T.; Desalegn, B.; Mitiku, E., Evaluation of Physicochemical Properties of Honey Produced in Bale Natural Forest, Southeastern Ethiopia. International Journal of Agricultural Science and Food Technology 2016, 2, 021-027.

[23] Agbagwa, O. E.; Otokunefor, T. V.; Nnenna, F. P., Quality Assessment of Nigeria Honey and Manuka Honey. Journal of Microbiology and Biotechnology Research 2011, 1, 20-31.

[24] Saxena, S.; Gautam, S.; Sharma, A., Physical, Biochemical and Antioxidant Properties of some Indian Honeys. Food Chemistry 2010, 118, 391-397.

[25] Akbulut, M.; Ozcan, M. M.; Coklar, H., Evaluation of Antioxidant Activity, Phenolic, Mineral Contents and some Physicochemical Properties of Several Pine Honeys Collected from Western Anatolia. International Journal of Food Science and Nutrition 2009, 60, 577-589.

[26] Ozcan, M. M.; Tastepe, B.; Arslan, D.; Unver, A., Some Qualitative Properties of Different Monofloral Honeys. Journal of Agroalimentary Processes and Technologies 2013, $19,355-361$.

[27] AOAC, Association of Official Analytical Chemists ( $16^{\text {th }}$ ed $)$. Official Methods of Analysis, 962.19: Washington, DC, 1999.

[28] Codex Alimentarius. Revised Codex Standard for Honey, Codex Stan. 12-1981, Rev. 1 (1987), Rev. 2 (2001), 2001, 12, $1-7$.

[29] Bogdanov, S.; Martine, P.; Lullmann C., Harmonized Methods of the International Honey Commission. Apidologie 1997, 159 .

[30] Lehotay S. J., Determination of Pesticide Residues in Foods by Acetonitrile Extraction and Partitioning with Magnesium Sulfate: Collaborative Study. Journal of Association Official Analytical Chemists International 2007, 90, 485-520.

[31] European Union (EU). Council Directive 2001/110/EC of $20^{\text {th }}$, December 2001 relating to honey. Official Journal of the European Communities, L10, 47-52, 2002.

[32] Ethiopia Standard (ES). Honey Specification: Ethiopian Standard, ES 1202:2005, First edition. Addis Ababa, Ethiopia, 2005.

[33] Finola, M. S.; Lasagno, M. C.; Marioli, J. M., Microbiological and Chemical Characterization of Honeys from Central Argentina. Food Chemistry 2007, 100, 1649-1653.
[34] Reshma, M. V.; Shyma, S.; George, T. M.; Rishin, A. V.; Ravi, K. C.; Shilu, L., Study on the Physicochemical Parameters, Phenolic Profile and Antioxidant Properties of Indian Honey Samples from Extrafloral Sources and Multi Floral Sources. International Food Research Journal 2016, 23, 2021-2028.

[35] Moniruzzaman, M.; Khalil, M. I.; Sulaiman, S. A.; Gan, S. H., Physicochemical and Antioxidant Properties of Malaysian Honeys Produced by Apis Cerana, Apis Dorsata and Apis Mellifera. BMC Complementary and Alternative Medicine 2013, 13, 1-12.

[36] Nascimento, A. S.; Marchini, L. C.; Carvalho, C. A. L.; Araújo, D. F. D.; Olinda, R. A.; Silveira, T. A., Physicalchemical Parameters of Honey of Stingless Bee (Hymenoptera: Apidae). American Chemical Science Journal 2015, 7, 139-149.

[37] Terrab, A.; Diez, M. J.; Heredia, F. J., Characterization of Moroccan Unifloral Honeys by their Physicochemical Characteristics. Food Chemistry 2002, 79, 373-379.

[38] Kumar, H. M.; Ananda, A. P.; Vishwanathan, D.; Siddagangaiah, D., Study of Physicochemical Parameters and Antioxidant in Honey Collected from Different Locations of India. International Journal of Pharmacy and Life Sciences 2013, 4, 3159-3165.

[39] Nanda, V.; Sarkar, B. C.; Sharmaa, H. K.; Bawa, A. S., Physicochemical Properties and Estimation of Mineral Content in Honey Produced from Different Plants in Northern India. Journal of Food Composition and Analysis 2003, 16, 613-619.

[40] Admasu, A.; Nuru, A., Effect of Honeybee Pollination on Seed Yield and Oil Content of Niger (Guizotia abyssinica): Proceedings of the First National Conference of Ethiopian Beekeepers Association, June 7-8, 1999, Addis Ababa, Ethiopia, 2000, 67-73.

[41] Manzoor, M.; Mathivanan, V.; Shah, G. N.; Mir, G. M.; Selvisabhanayakam. Physico-chemical Analysis of Honey of Apis Cerana Indica and Apis Mellifera from Different Regions of Anantnag District, Jammu and Kashmir. International Journal of Pharmacy and Pharmaceutical Sciences 2013, 5, 635-638.

[42] Lawal, R. A.; Lawal, A. K.; Adekalu, J. B., Physicochemical Studies on Adulteration of Honey in Nigeria. Pakistan Journal of Biological Sciences 2009, 12, 1080-1084.

[43] World Health Organization (WHO), Guidelines for Predicting Dietary Intake of Pesticide Residues (revised). Global Environment Monitoring System- Food Contamination and Assessment Programme (GEMS/Food) in Collaboration with Codex Committee on Pesticide Residues, 1997.

[44] Food and Agriculture Organization (FAO), Submission and Evaluation of Pesticide Residues Data for the Estimation of Maximum Residue Levels in Food and Feed ( $1^{\text {st }}$ ed.). Rome, 2002. 